\title{
APPLICATION OF COMPUTER PROGRAMMES IN RESEARCH PROJECTS AND TEACHING
}

\author{
Pawel Ptak \\ Czestochowa University of Technology, Faculty of Electrical Engineering Poland
}

\begin{abstract}
Integrated software packages, such as National Instruments Multisim or DasyLab can be successfully applied in developing research projects and in teaching. Thanks to their intuitive use and wide potential they can be utilised as support for simulation and other programmes. They are also often applied for comparative analysis of real measurement results with computer simulations. Apart from that, they can also be useful in a research or experimental lab.
\end{abstract}

Keywords: software packages, simulation, teaching.

\section{Introduction}

With the development of Information Technology, it has become possible to create software aiding design of electronic systems used for carrying out measurements in research and in teaching. This kind of software can be divided into two categories: one includes programmes for improving and automatising measurements and further processing of data, and the other includes programmes for constructing and simulating virtual electronic and digital systems and circuits (Winiecki, 2001; Rak, 1999).

DasyLab belongs to the first category. It offers facilities for connecting function blocks to represent the data flow. In this way, a measuring environment is created, which can be used both for simulations and for real measurements. Simulations, in turn, may improve measurements as well as data processing without access to the object under test. A measuring system constructed in this way can be used for real measurements when a measuring card is connected with the computer and data are collected from such an object (Ptak \& Prauzner, 2013). Individual icons in the programme, the settings and parameters of which can be adjusted at any time, represent particular function blocks (Ptak \& Prauzner, 2010). The blocks representing single measuring functions can be connected in a number of configurations, which can be modified and expanded as needed. Data obtained in real or simulated measurements can be saved in files so that they can be used for mathematical or statistical analyses at a later time (Ptak \& Borowik, 2012). Having been processed, the measuring data can also be 
analysed in a number of ways and the results obtained are available for further processing by means of special software dedicated to data analysis (Ptak \& Prauzner, 2014). Additionally, they can be used for development and expansion of the measuring system.

The programme offered by National Instruments Multisim Education is an example of software from the other category. It can be used for constructing many complicated electronic and digital measuring and test systems. They consist of both real electronic components as well as models of ideal components which could be used in the designed measuring system. Each type together with corresponding flow paths is marked with a different colour, so that it is possible to use either real elements only, or virtual elements with ideal parameters only, or both at the same time. Operation of a complete measuring system can be analysed by studying output signals and operation of a simulated system. The software package includes real measuring instruments and a representation of the front panel with control systems, which look and operate in the same way as real ones.

As evident, both DasyLab and Multisim software packages can play an important role in the process of designing a research project, in measurements carried out as part of such a project, as well as in the simulation and modelling of real digital and electronic systems (Ptak, 2015). The two packages can complement each other. Multisim can be used for designing electronic systems and for analysing data from measuring sensors, used for data acquisition and preliminary processing. The operation of such systems can be tested at the design stage by simulating and modelling their operation under real measuring conditions (Ptak, 2016). DasyLab, in turn, can be used for automatizing the measuring process by eliminating the need to operate the system by a user. Besides, it can be applied as a programme supporting data acquisition from measuring systems and for subsequent processing of that data. Applying both software packages at once offers a possibility of designing an electronic system for preliminary data processing by means of Multisim and for their further processing by means of DasyLab, with the whole research and testing process being fully automatic (Ptak \& Borowik, 2014). Thanks to the fact that the system can operate both under simulated and real conditions (Ptak \& Borowik 2015), it is possible to design and test it in a laboratory and then to expand and adapt it to real measuring and research conditions (Klajny et al., 2007; Migo \& Noga, 2015).

\section{Applications of the Multisim and DasyLab packages}

Electronic filters are widely applied in various research projects. The most typical construction includes an operational amplifier employed in various 
systems, typically with a band-pass (low-, high- or medium-pass) filter. Fig. 1 presents a diagram of high-pass filter based on an op-amp type TL072A, which has been designed by means of Multisim. Two modules are added to the system: the module of functional signal generator and the module of oscilloscope for displaying an output signal.

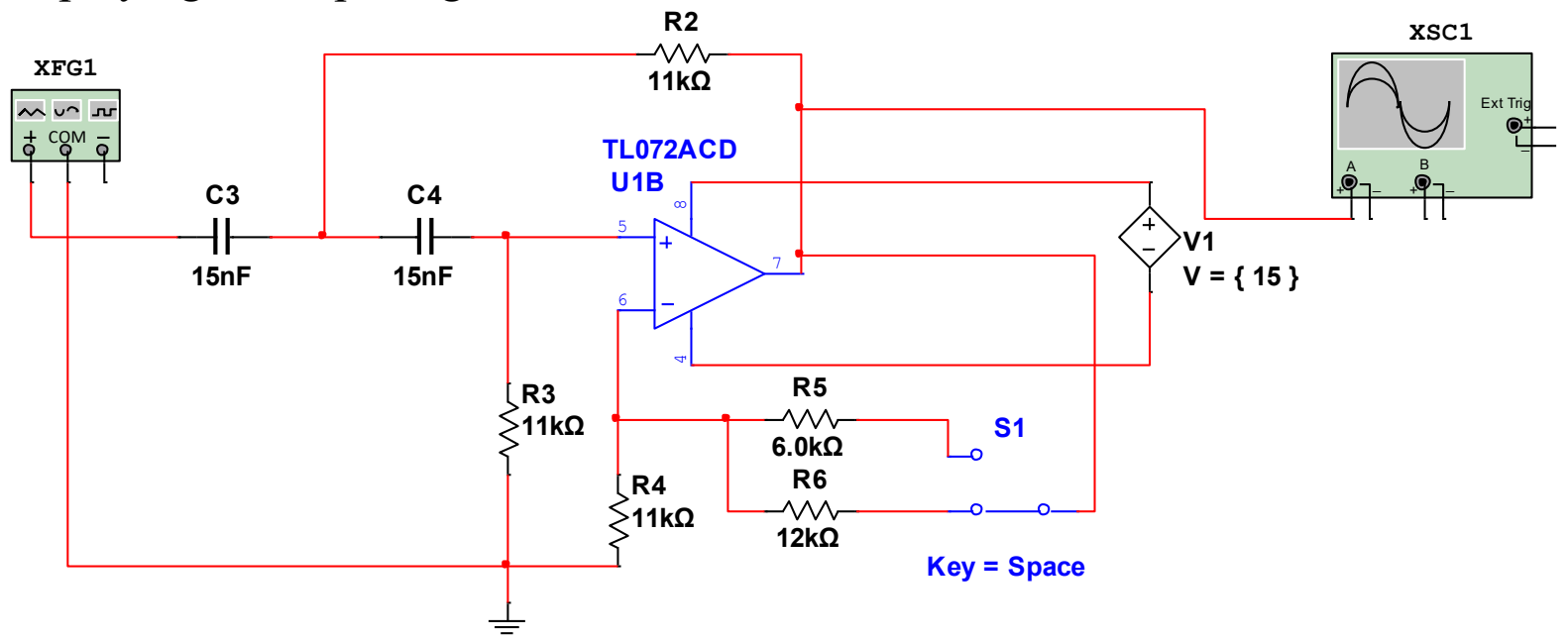

Fig.1 Diagram of a high-pass filter system constructed by means of Multisim

Fig. 2 presents a working simulation of the high-pass filter system with an input signal curve displayed on the oscilloscope and with the control elements of the function generator.

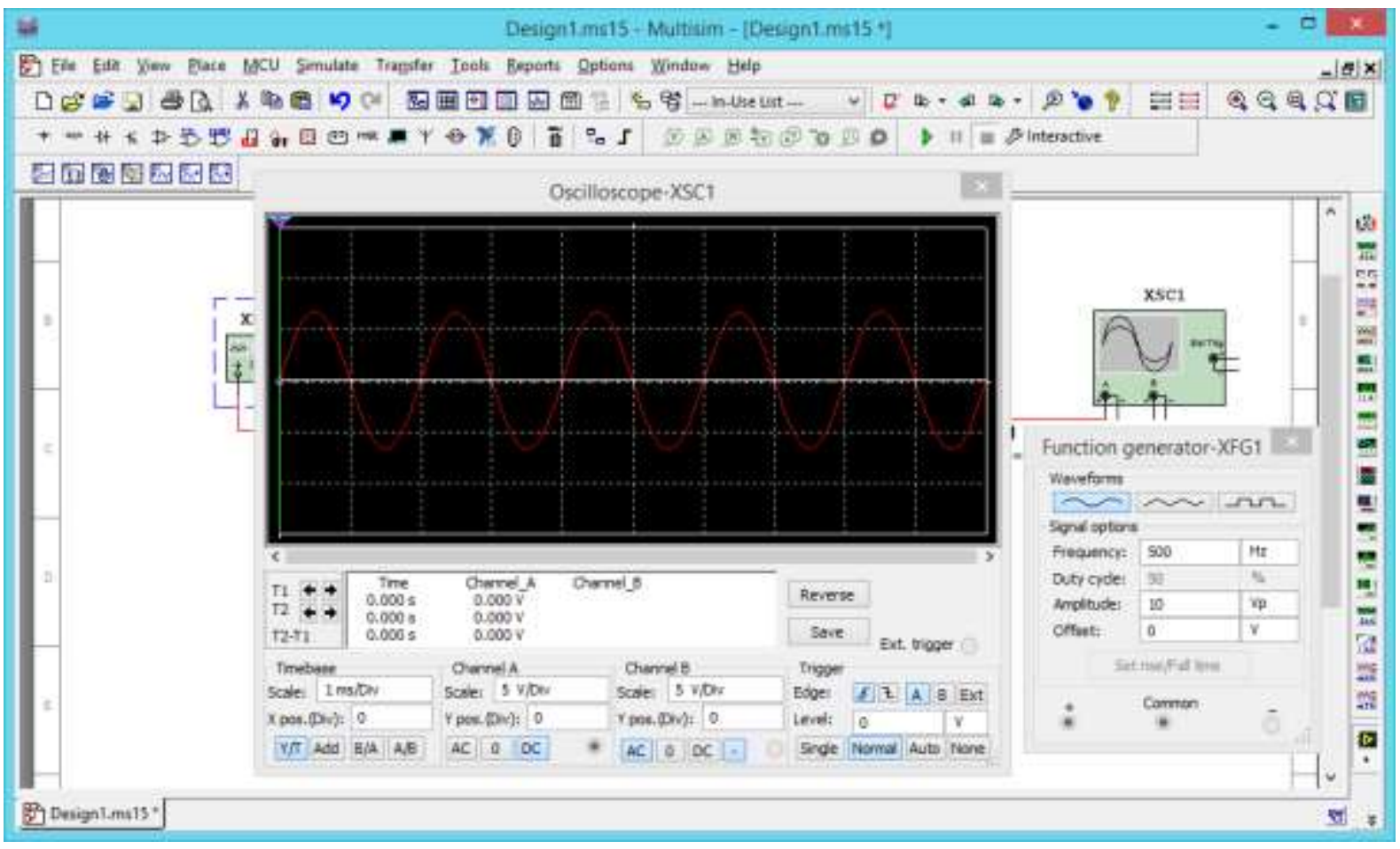

Fig.2 Simulation of the high-pass filter system, the input signal curve and the control elements of the function generator 
All the components of the filter, such as resistances and capacities, can be modified at the stage of designing and when the simulation programme is running. It is also possible to modify the parameters of the function generator powering the high-pass filter system. A signal simulated by the generator is variable in time and is modified by the electronic filter system. When the generator is replaced by signals received by a measuring card, the system can be applied for filtering real data obtained from objects under test. In this way, the programme Multisim can be utilised for constructing the filter system, starting from a design, through simulating its operation, to its practical applications.

The DasyLab package has been used for designing a measuring system for examining parameters of signals varying in time. Such signals are often utilised in inductive sensors, which can be applied for testing the thickness of protective coatings or other material parameters in power, automotive or machine industry. The system constructed by means of the programme DasyLab is used for data acquisition from measuring sensors and for the further processing of the data to obtain characteristic parameters of the object under test. In order to simulate signals from measuring sensors, function generators with adjustable operating parameters were used. Fig. 3 presents a measuring system constructed by means of DasyLab. The icons correspond to modules performing specific functions in the simulation.

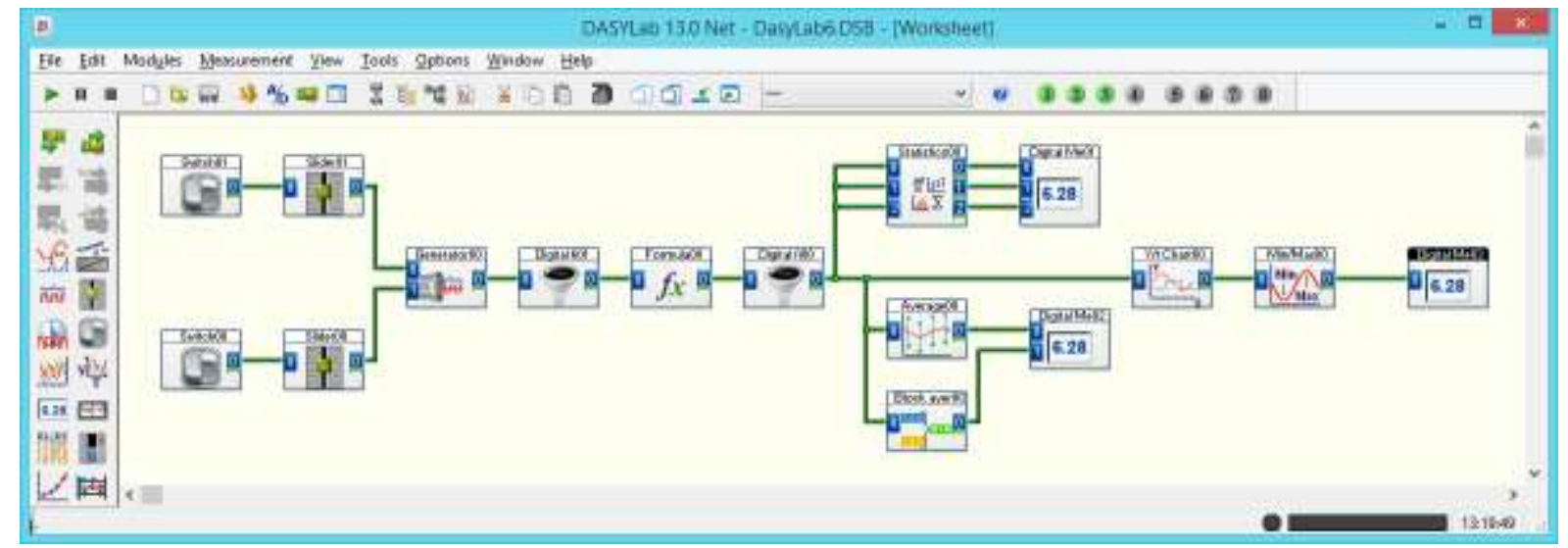

Fig.3 Diagram of a measuring system constructed in DasyLab

The modules represent the system operation. Starting from the left-hand side with measuring signal simulation together with control elements, then signal filtering, amplification, averaging, performing statistical operations on the package of data and ultimately representing the results graphically, so that the maximal and average values of a signal are shown.

Fig. 4 presents a running simulation of the DasyLab-based measuring system. Apart from the block diagram of the system, there are control elements, 
digital displays showing the current results of running operations and a virtual oscilloscope displaying the measuring signal after being processed by the consecutive functional blocks.

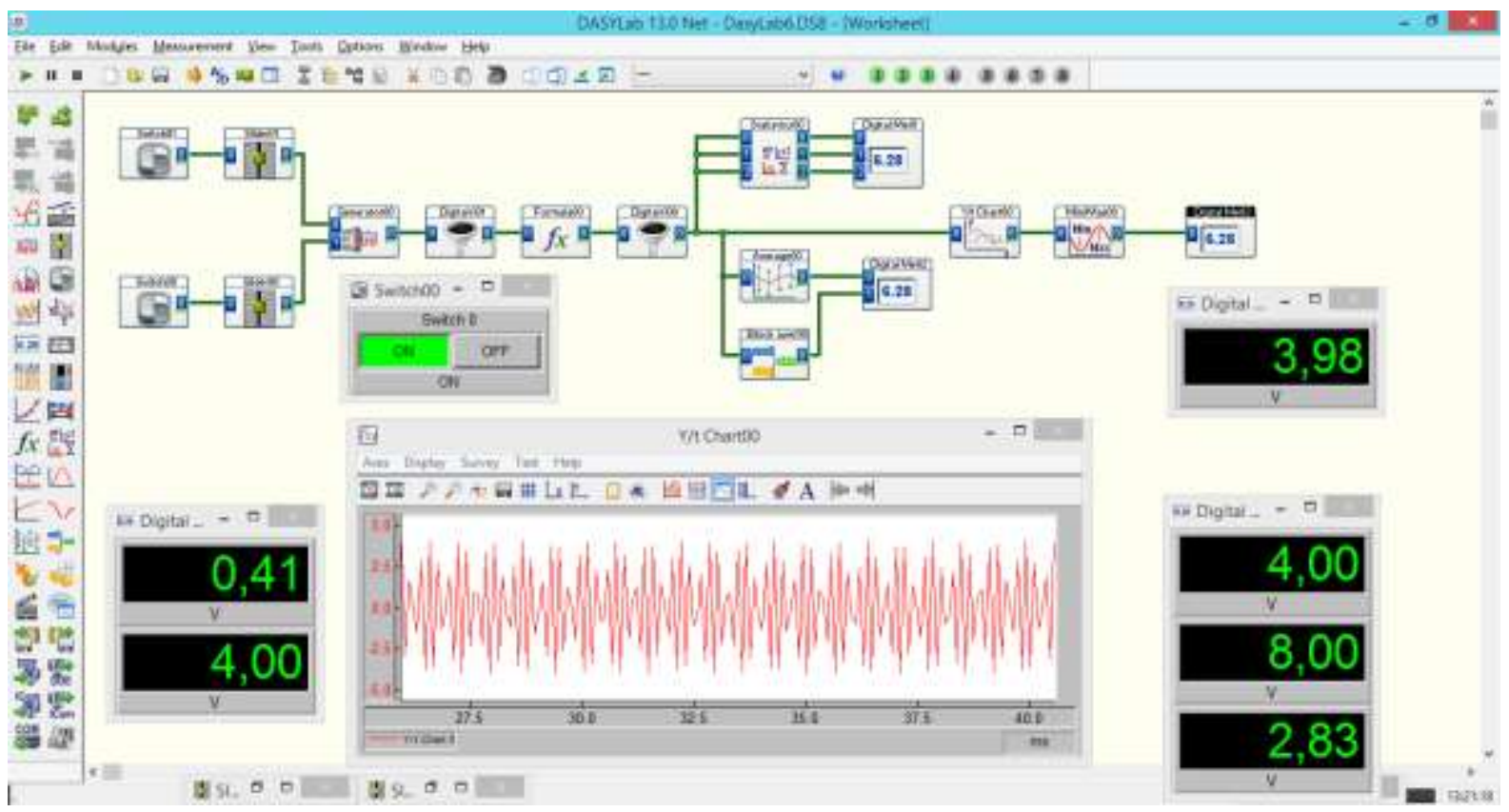

Fig.4 A running simulation of the DasyLab-based measuring system

Fig. 5 illustrates an expanded version of the diagram presented in Fig. 2, with an additional module of averaging the measuring signal on the basis of a data block of a certain length. Fig. 6 presents operation of this system simulated in the programme DasyLab.

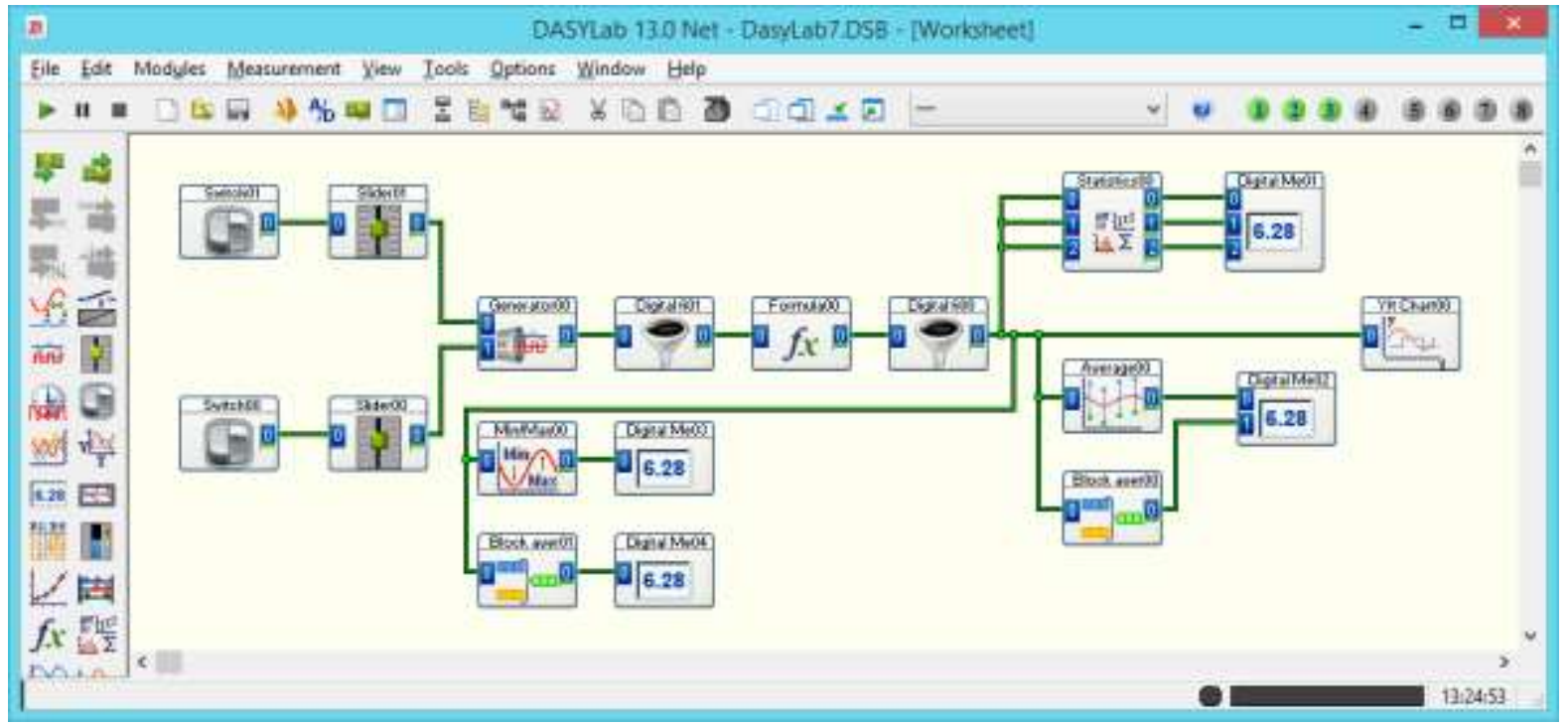

Fig.5 A modified measuring system constructed by means of DasyLab 


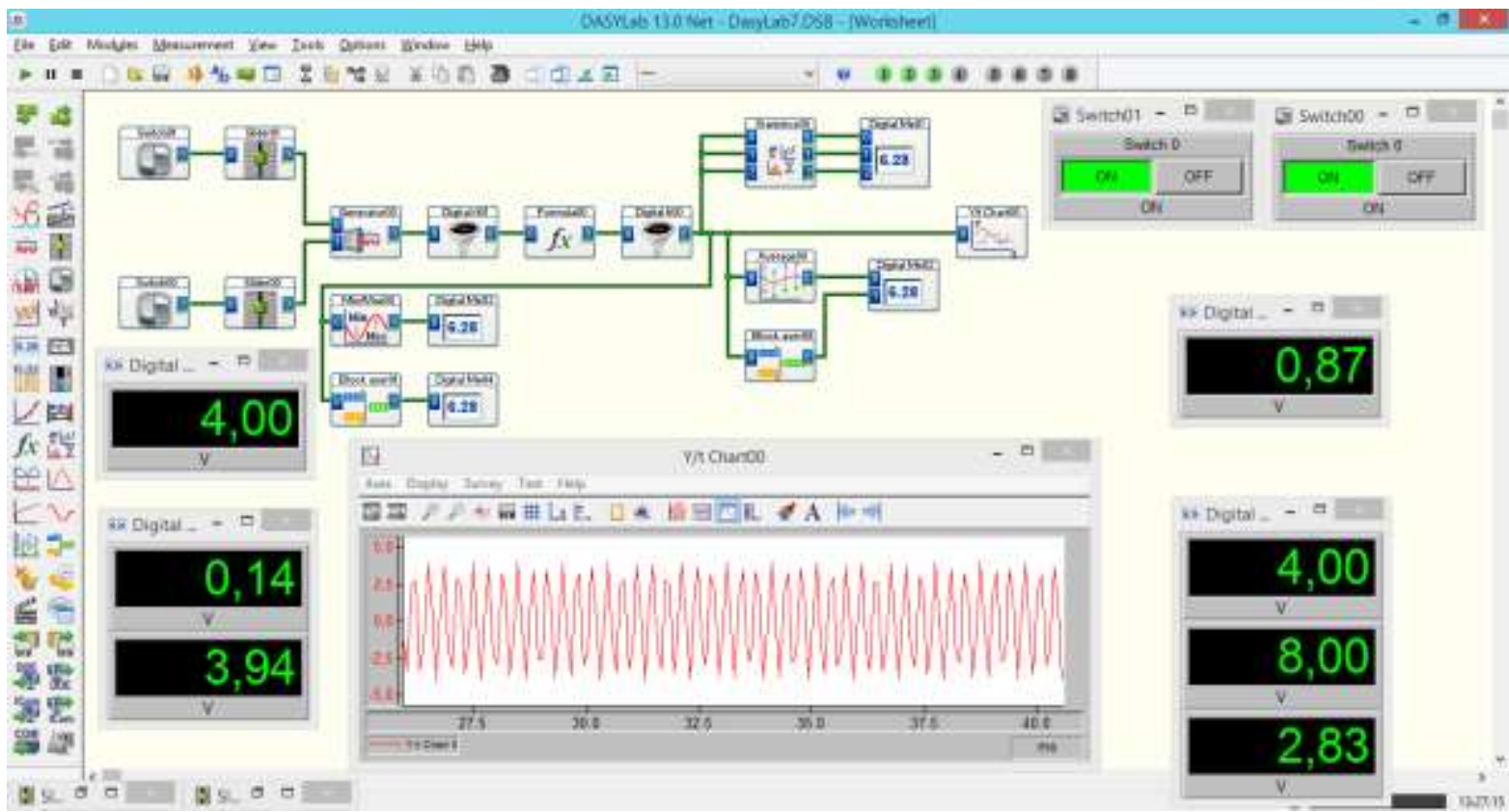

Fig.6 The modified measuring system operation simulated by means of DasyLab

Fig. 7 presents simulated operation of another expanded version of the measuring system, with a module of measuring data presentation in the form of a data matrix and with a block of saving the measuring data in a file. Measuring data saved in a file can be further processed by means of programmes dedicated especially to the analysis of research data, or they can be used as a starting point for further investigations.

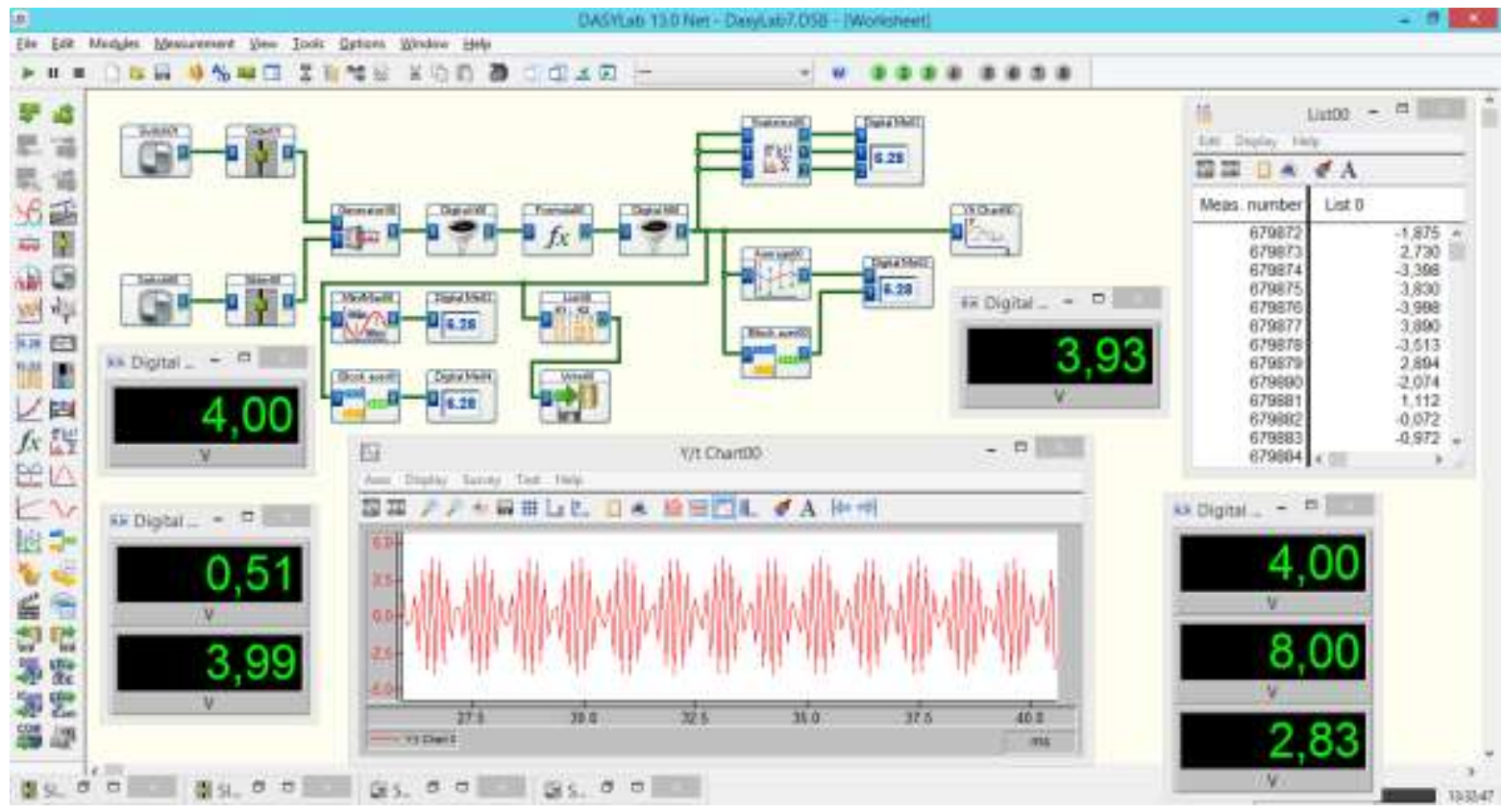

Fig.7 The expanded measuring system during simulated operation in the DasyLab environment 
The subsequent screens present further expansion of the measuring system. This time a FFT module has been added for performing a frequency analysis of the measuring signal consisting of a number of component frequencies. The components of such a signal constitute a percentage share in the total power of a complex signal and their by analysing them by means of the function block FFT it is possible to assess the values of the components of the measuring signal received from an object under test. Fig. 8 presents a diagram of the function blocks of the system, and Fig. 9 shows operation of the system simulated in the DasyLab environment.

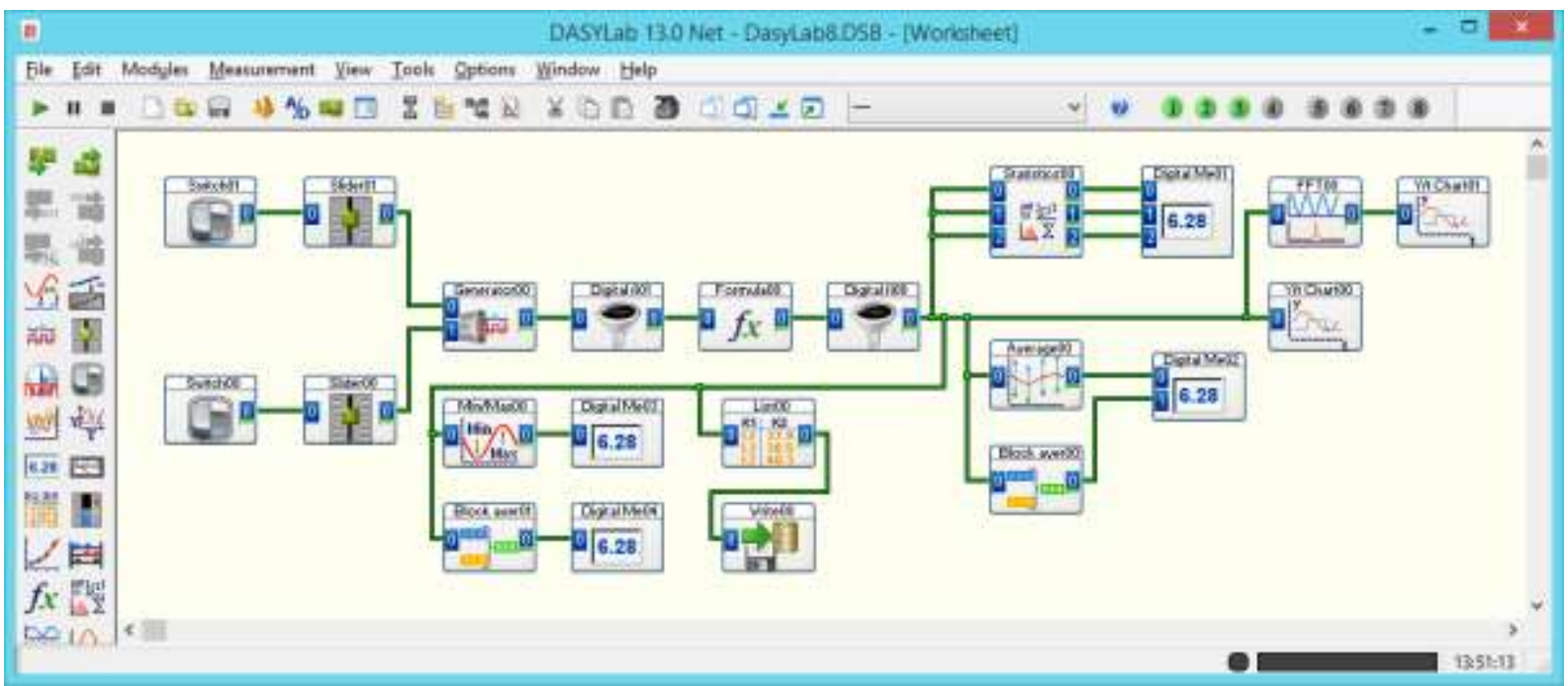

Fig. 8 Another expanded version of the measuring system constructed by means of DasyLab

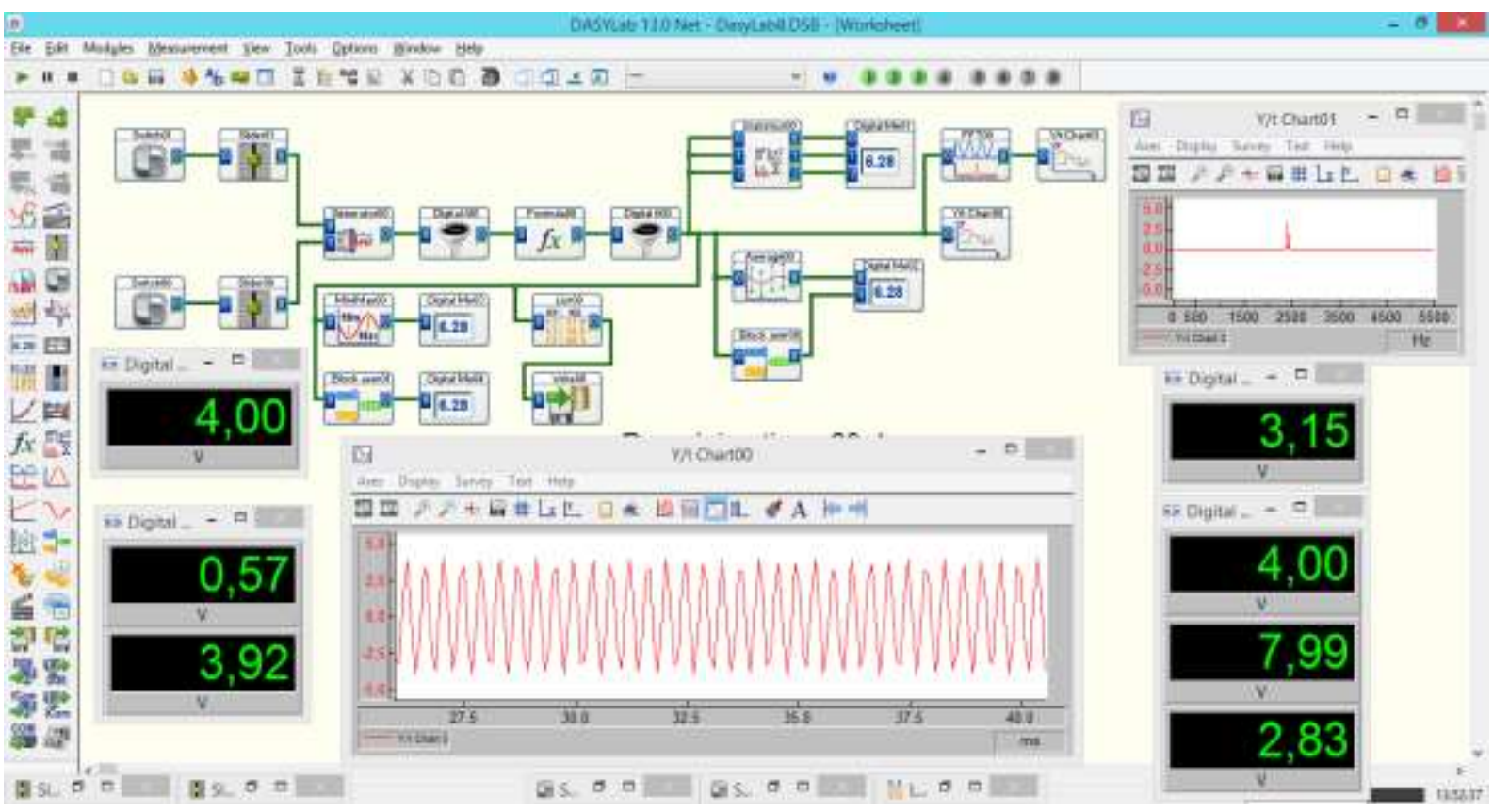

Fig.9 The final version of the measuring system operating in the DasyLab 
The figures present selected stages of designing and simulation of the measuring system constructed in the DasyLab environment. During the process of designing the system it is possible to introduce modifications and to test how they impact its operation. Modifications can involve changes in selected connections between the function blocks or adding new functions to expand the system's scope of applications. The parameters of individual function blocks can be modified as well, so that they optimally meet the user's requirements.

Modelling the investigation process or designing measuring systems is an indispensable part of teaching of technological subjects and also a part of research projects (Olesiak, 2013; Jakubiec, 2016). Simulations are often applied as preliminary research methods, which are subsequently verified by real measurements of an object under study (Prauzner, 2014; Prauzner, 2015; Zloto et al., 2012). Simulations can also be applied for verifying the effectiveness of modelling used as a teaching method, as mentioned above (Prauzner, 2012; Prauzner, 2016). Simulations can be used as an independent method, when there is no access to measuring equipment or an object under test, or they can be treated as supplementary with respect to the classical method based on empirical testing (Depesova et al., 2008; Noga, 2009; Noga et al., 2014).

\section{Concluding remarks}

- The design of the measuring system can be modified by students as their individual assignment and as preparation for the class (Prauzner, 2015). This task does not require a laboratory; it can be performed using any PC with Multisim- or DasyLab - type software.

- The measuring system can be easily tested virtually by carrying out a simulation. Then, should there be such a need, it can be adapted to the requirements of empirical measurements.

- Software packages, such as Multisim and DasyLab, are very useful in designing a measuring system using only a computer, if for some reason, e.g. high cost or equipment availability, it is not possible to do so in the real research or didactic laboratory conditions.

- Modifications of the measuring system can be simulated without altering the setup of the research equipment, which makes it possible to test the results of such modifications without risking a damage of the equipment.

\section{References}

Depesova, J., Vargova, M., \& Noga, H. (2008). Edukacja techniczno informatyczna $w$ opinii nauczycieli. Uniwersytet Pedagogiczny, Kraków, pp. 149-157 
Jakubiec, B. (2016). Computer model of electric vehicle drive system fed from hybrid energy storage system (Model napędu pojazdu elektrycznego $\mathrm{z}$ hybrydowym zasobnikiem energii), Przegląd Elektrotechniczny (Electrical Review) 92 (2016), nr 12, pp. 57-60. ISSN 0033-2097

Klajny, T., Krzywanski, J., \& Nowak, W. (2007). Mechanism and Kinetics of coal combustion in oxygen enhanced conditions. Proc. of the 6th International Symposium on Coal Combustion, Wuhan, China, December 1-4, pp. 148-153.

Noga, H. (2009). Sociometric methods in technological and information technology education. In: Trends in Education. Information technologies and technical education. Olomouc, Vols.1, pp. 165-169

Noga, H., Piaskowska-Silarska, M., Depešová, J., Pytel, K., \& Migo, P. (2014). Neuro didactic erspective of creative attitude towards education in the third millennium examination of individual cases. In: Emerging eLearning Technologies and Applications (ICETA), 2014 IEEE 12th International Conference on. pp. 355-360

Migo, P., \& Noga, H. (2015). Start-up of SSTC semiconductor tesla coil - an example of an educational project. Przeglad Elektrotechniczny, Volume 1, Issue 12, 2015, pp. 167-169.

Olesiak, K. (2013). Selected Problems of the Asynchronous Drive Control with the Threephase Soft-start System. Conference: Symposium on Mechatronics Systems, Mechanics and Materials, Jastrzebia Gora, Poland, October 09-10 2013, Mechatronic Systems, Mechanics And Materials II, Book Series: Solid State Phenomena, Vol. 210, pp. 245251.

Prauzner, T. (2012). Zakłócenia elektromagnetyczne w elektronicznych systemach alarmowych. (The electromagnetic interferences in the electronic alarm systems). In: Przeglad Elektrotechniczny, 88 (2012), nr.12b, pp. 205-208.

Prauzner, T. (2014). Effectiveness of magnetic detectors in alarm systems. Przeglad Elektrotechniczny, R. 90 NR 12/2014, pp. 269-272.

Prauzner, T. (2014). Modelowanie działania czujki magnetycznej w programie Quckfield jako przykład wykorzystania e-technologii w metrologii elektrycznej. Zeszyty Naukowe Wydziatu Elektrotechniki i Automatyki Politechniki Gdańskiej Nr 37, E-Technologies in Engineering Education, Politechnika Gdańska, pp. 125-129

Prauzner, T. (2015). Analysis of the results of the pedagogical research and EEG in the aspect of effective modern teaching aids in the technical education. In: Society. Integration. Education, Proceedings of the International Scientific Conference. Volume IV, Latvia, Rezekne, May 22th-23th 2015, pp. 480-489. http://dx.doi.org/10.17770/sie2015vol4.414

Prauzner, T. (2015). Finite Element Method in an analysis of selected parameters of an inductive sensor for protective coatings measurements. Przeglad Elektrotechniczny, 91 (2015), nr.12, pp. 205-208.

Prauzner, T. (2016). Interactive computer simulation as a response to contemporary problems of technical education. In: Society. Integration. Education, Proceedings of the International Scientific Conference. Volume II, May 27th - 28th 2016, Rēzekne, Latvia. http://dx.doi.org/10.17770/sie2016vol2.1415

Ptak, P., \& Borowik, L. (2012). Diagnostyka zabezpieczeń antykorozyjnych na potrzeby elektroenergetyki. Przeglad Elektrotechniczny, nr 09a, pp. 142-145.

Ptak, P., \& Borowik, L. (2014). Dokładność czujników indukcyjnych w defektoskopii warstw ochronnych urządzeń elektrycznych. Przegląd Elektrotechniczny, R. 90 NR 12/2014, pp. 277-280.

Ptak, P., \& Borowik, L. (2015). Badanie wielowarstwowych powłok ochronnych. Przeglad Elektrotechniczny, R. 91 NR 12/2015, pp. 209-211. 
Ptak, P., \& Prauzner, T. (2010). Wykorzystanie pakietu DasyLab w nauczaniu podstaw elektroniki. Edukacja. Studia, Badania, Innowacje, NR 02/2010, pp. 159-164.

Ptak, P., \& Prauzner, T. (2013). Badanie czujników detekcji zagrożeń w systemach alarmowych. Przeglad Elektrotechniczny, NR 10/2013, pp. 274-276.

Ptak, P. (2015). Application of DasyLab in Teaching Electrical Engineering. Society, Integration, Education. Proceedings of the International Scientific Conference. Volume IV, May 22nd-23rd, 2015. Rēzekne: Rēzeknes Augstskola, Latvia, 2015, pp. 490-499.

Ptak, P. (2016). Application of software packages in research and didactics. Society, Integration, Education. Proceedings of the International Scientific Conference. Volume II, May 27th-28th, 2016. Rēzekne: Rēzeknes Augstskola, Latvia, 2016. pp. 589-597.

Rak, J. R. (1999). Wirtualne przyrządy pomiarowe. Białystok, XXXI Międzyuczelniana Konferencja Metrologów MKM'99.

Winiecki, W. (2001). Graficzne zintegrowane środowiska programowe. Warszawa, PL: Wyd. Mikom.

Zloto, T., Ptak, P., \& Prauzner, T. (2012). Analysis of signals from inductive sensors by means of the DasyLab software. Annales Universitatis Mariae Curie-Skłodowska Sectio AI Informatica XII, NR 1/2012, 31-37. 